\title{
Prevalensi stomatitis nikotina pada buruh tambang yang memiliki kebiasaan merokok
}

\author{
${ }^{1}$ Filliany A. P. Siwi \\ ${ }^{2}$ Damajanty H. C. Pangemanan \\ ${ }^{3}$ Paulina N. Gunawan
}

\author{
${ }^{1}$ Kandidat Skripsi Program Studi Pendidikan Dokter Gigi Fakultas Kedokteran \\ ${ }^{2}$ Bagian Fisiologi Fakultas Kedokteran \\ ${ }^{3}$ Program Studi Pendidikan Dokter Gigi Fakultas Kedokteran \\ Universitas Sam Ratulangi Manado \\ Email: fillianys@yahoo.com
}

\begin{abstract}
Smoking is one of the causes of death that is already known by most people. Besides that, smoking can cause several diseases in the oral cavity, inter alia nicotinic stomatitis. Although there are many bad effects of smoking, the prevalence of smokers in Indonesia is still increasing. Miners belong to the largest proportion of active smokers. This study was aimed to obtain the prevalence of nicotinic stomatitis among the miners who had smoking habit. This was a descriptive analytical study with a cross sectional design. This study was conducted at Ratatotok mining with a population of 1.463 miners. Subjects were 94 miners obtained by using simple random sampling. The results showed that there were 78.7\% of subjects that had nicotinic stomatitis. Based on the types of cigarette, the majority (53.3\%) smoked white cigarette. Based on the duration of smoking, most subjects had smoking habbit for $>20$ years $(38.3 \%)$. Moreover, based on the number of cigarettes smoked each day, most subjects (44.7\%) smoked more than 20 cigarettes per day. Conclusion: The majority of miners that suffered from nicotinic stomatitis smoked white cigarettes, had smoking habit for more than 20 years, and smoked more than 20 cigarettes per day.
\end{abstract}

Keywords: smoking habit, nicotinic stomatitis

\begin{abstract}
Abstrak: Rokok termasuk salah satu penyebab kematian yang umumnya telah diketahui oleh sebagian besar masyarakat. Selain penyebab kematian, rokok juga dapat menyebabkan penyakit dalam rongga mulut, salah satunya yaitu stomatitis nikotina. Meskipun banyak dampak buruk dari rokok namun prevalensi perokok di Indonesia semakin meningkat. Buruh tambang merupakan salah satu jenis pekerjaan yang mempunyai proporsi terbesar perokok aktif. Penelitian ini bertujuan untuk mengetahui prevalensi stomatitis nikotina pada buruh tambang yang memiliki kebiasaan merokok. Jenis penelitian ialah deskriptif analitik dengan desain potong lintang. Penelitian dilakukan di wilayah pertambangan Kecamatan Ratatotok dengan jumlah populasi buruh tambang yang terdaftar sebanyak 1463 orang. Subyrk pernelitian sebanyak 94 orang diperoleh dengan metode simple random sampling. Hasil penelitian menunjukkan bahwa subjek penelitian dengan stomatitis nikotina sebanyak $78,7 \%$. Subjek penelitian yang terlihat adanya stomatitis nikotina berdasarkan jenis rokok paling banyak pada subjek yang merokok dengan jenis rokok putih $(55,3 \%)$. Berdasarkan lama merokok paling banyak pada subjek yang sudah merokok $>20$ tahun $(38,3 \%)$, dan berdasarkan jumlah rokok yang dihisap setiap hari paling banyak pada subjek yang merokok $>20$ batang per hari $(44,7 \%)$. Simpulan: Sebagian besar buruh tambang yang menderita stomatitis nikotina menghisap rokok dengan jenis rokok putih, sudah merokok selama $>20$ tahun, dan merokok >20 batang per hari.
\end{abstract}

Kata kunci: kebiasaan merokok, stomatitis nikotina 
Rokok merupakan benda yang sudah tidak asing lagi di masyarakat kita. Begitu pula merokok sudah menjadi kebiasaan yang lazim ditemui dalam kehidupan sehari-hari dan meluas di masyarakat. Telah diketahui bahwa rokok merupakan salah satu penyebab kematian. ${ }^{1}$ Selain itu, rokok juga merupakan penyebab dari kanker, serangan jantung, impotensi dan gangguan kehamilan dan janin yang sebagian besar masyarakat sudah mengetahui hal tersebut, tetapi efek dari merokok terhadap penyakit mulut belum banyak yang mengetahuinya. Efek merokok pada rongga mulut salah satunya ialah stomatitis nikotina. ${ }^{2}$

Stomatitis nikotina merupakan lesi putih yang terdapat pada daerah palatum durum dari perokok berat. Meskipun kebiasaan merokok berdampak buruk pada kesehatan, tapi prevalensi perokok tetap meningkat. $^{3} \quad$ Peningkatan prevalensi merokok di negara berkembang termasuk di Indonesia menyebabkan masalah konsumsi rokok menjadi semakin serius. ${ }^{4}$ Merokok sudah menjadi suatu kebutuhan yang tidak dapat dielakkan sehingga merokok dianggap hal yang biasa bagi sebagian perokok di Indonesia. Bahkan hari tanpa tembakau sedunia yang diperingati pada tanggal 31 Mei tidak menyurutkan perokok untuk mengurangi kebiasaanya. ${ }^{5}$

Lembaga Global Adult Tobacco Survey (GATS) tahun 2011 menyatakan bahwa Indonesia merupakan salah satu negara dengan tingkat prevalensi perokok tertinggi di dunia. ${ }^{6}$ Menurut data Riset Kesehatan Dasar (RISKESDAS) tahun 2013 prevalensi perokok di Indonesia mencapai $36,3 \%$ dan di Sulawesi Utara prevalensi penduduk berusia $\geq 10$ tahun yang merokok setiap hari lebih tinggi dibandingkan prevalensi nasional $(24,3 \%)$ yaitu sebesar $24,6 \%{ }^{7}$

Perokok terdiri dari berbagai kelas sosial, status, serta kelompok usia yang berbeda. ${ }^{8}$ Bagi sebagian orang rokok sudah menjadi kebutuhan hidup yang tidak bisa ditinggalkan dalam kehidupan sehari-hari. Nelayan dan buruh merupakan perokok aktif setiap hari yang mempunyai proporsi terbesar yaitu $44,5 \%$ dibandingkan kelompok pekerjaan lainnya.

Hasil penelitian tahun 2012 oleh Mentang $^{10}$ tentang gambaran lesi yang diduga stomatitis nikotina pada perokok di pelabuhan Manado, menunjukkan sebanyak $58 \%$ subjek terlihat adanya lesi yang diduga stomatitis nikotina.

Kecamatan Ratatotok merupakan salah satu kecamatan yang letaknya di wilayah pesisir pantai dan satu-satunya kecamatan di Kabupaten Minahasa Tenggara yang memiliki wilayah tambang emas. Sosial ekonomi serta latar belakang pendidikan masyarakatnya masih rendah karena sebagian besar berprofesi sebagai buruh tradisional. Sebagian besar buruh merupakan buruh tambang yang memiliki kebiasaan merokok cukup tinggi. Penyuluhan kesehatan tentang kesehatan gigi dan mulut pada perokok juga jarang dilakukan khususnya di Kecamatan Ratatotok.

Penelitian ini bertujuan untuk mengetahui prevalensi stomatitis nikotina pada buruh tambang di Kecamatan Ratatotok yang memiliki kebiasaan merokok berdasarkan jenis, lama dan jumlah rokok yang dikonsumsi.

\section{BAHAN DAN METODE PENELITIAN}

Jenis penelitian ini ialah deskriptif analitik yang menggunakan desain potong lintang. Penelitian ini dilaksanakan di Kecamatan Ratatotok pada bulan AgustusSeptember 2016. Populasi dalam penelitian ini ialah seluruh buruh tambang yang memiliki kebiasaan merokok di Kecamatan Ratatotok sebanyak 1463 orang. Pengambilan sampel dilakukan dengan menggunakan metode simple random sampling dengan jumlah sampel yaitu 94 orang.

Subjek penelitian berdasarkan titik tolak pada ciri-ciri kriteria yaitu kriteria inklusi dan kriteria eksklusi. Yang termasuk kriteria inklusi ialah laki-laki dewasa berusia 20 - 60 tahun, dan memiliki kebiasaan merokok lebih dari 20 batang per hari selama sekurang-kurangnya 1 tahun sampai pada saat penelitian (perokok rutin). Kriteria eksklusi ialah menolak turut serta 
dalam penelitian dan menggunakan gigi tiruan rahang atas.

Pengolahan dan analisis data pada penelitian ini adalah pengumpulan data pimer dan sekunder. Data primer diperoleh langsung dari subjek penelitian melalui formulir pemeriksaan dan data sekunder diperoleh dari kantor kecamatan berupa data populasi buruh tambang. Seluruh data yang didapatkan dalam penelitian ini diolah dengan sistem komputerisasi (microsoft excel) dan disajikan dalam bentuk tabel.

\section{HASIL PENELITIAN}

Distribusi responden penelitian berdasarkan jenis rokok, lama merokok, dan jumlah rokok pada penelitian ini dapat dilihat pada Tabel 1, 2, dan 3.

Tabel 1. Distribusi responden berdasarkan jenis rokok

\begin{tabular}{lcc}
\hline Jenis rokok & Frekuensi (n) & \% \\
Putih & 64 & 68,1 \\
Kretek & 1 & 1,1 \\
Campuran & 29 & 30,8 \\
Total & 94 & 100 \\
\hline
\end{tabular}

Tabel 2. Distribusi responden berdasarkan lama merokok

\begin{tabular}{ccc}
$\begin{array}{c}\text { Lama } \\
\text { merokok }\end{array}$ & $\begin{array}{c}\text { Frekuensi (n) } \\
\text { (tahun) }\end{array}$ & $(\boldsymbol{\%})$ \\
\hline $1-10$ & 25 & 26,6 \\
$>10-20$ & 27 & 28,7 \\
$>20$ & 42 & 44,7 \\
Total & 94 & 100 \\
\hline
\end{tabular}

Tabel 3. Distribusi responden berdasarkan jumlah rokok yang dihisap setiap hari

\begin{tabular}{ccc}
\hline $\begin{array}{c}\text { Jumlah rokok } \\
\text { (batang per hari) }\end{array}$ & $\begin{array}{c}\text { Frekuensi } \\
\text { (n) }\end{array}$ & \% \\
\hline$<10$ & 15 & 16,0 \\
$10-20$ & 32 & 34,0 \\
$>20$ & 47 & 50,0 \\
Jumlah & 94 & 100 \\
\hline
\end{tabular}

Tabel 4 menunjukkan bahwa dari 94 responden yang diperiksa, terdapat sebanyak 74 responden $(78,7 \%)$ dengan stomatitis nikotina.

Tabel 4. Distribusi stomatitis nikotina pada responden penelitian

\begin{tabular}{ccc}
\hline $\begin{array}{c}\text { Stomatitis } \\
\text { nikotina }\end{array}$ & $\begin{array}{c}\text { Frekuensi } \\
(\mathbf{n})\end{array}$ & \% \\
\hline Ada & 74 & 78,7 \\
Tidak & 20 & 21,3 \\
Jumlah & 94 & 100 \\
\hline
\end{tabular}

Tabel 5 menunjukkan bahwa dari 64 responden yang menghisap rokok putih terdapat 52 responden $(55,3 \%)$ dengan stomatitis nikotina, Pada satu responden $(1,1 \%)$ yang menghisap rokok kretek dan 21 responden $(72,4 \%)$ yang menghisap rokok rokok campuran juga terlihat adanya stomatitis nikotina.

Tabel 6 menunjukkan bahwa dari 25 responden yang sudah merokok selama 110 tahun terdapat 18 responden $(19,1 \%)$ dengan stomatitis nikotina; dari yang sudah merokok selama 10-20 tahun terdapat 20 responden $(21,35)$ dengan stomatitis nikotina; dan dari yang sudah merokok selama >20 tahun terdapat 36 responden $(38,3 \%)$ dengan stomatitis nikotina.

Berdasarkan Tabel 7 diketahui bahwa dari 9 responden yang menghisap rokok $<10$ batang per hari terdapat 7 responden $(7,4 \%)$ dengan stomatitis nikotina; dari yang menghisap rokok 10-20 batang per hari terdapat sebanyak 25 responden (26,6\%) dengan stomatitis nikotina; dan dari yang menghisap rokok $>20$ batang per hari terdapat 42 responden $(44,7 \%)$ dengan stomatitis nikotina.

\section{BAHASAN}

Stomatitis nikotina merupakan lesi putih yang terdapat pada palatum durum dari perokok berat, perokok pipa, dan perokok cerutu. ${ }^{11,12}$ Penelitian yang dilakukan oleh Darongke et al. ${ }^{13}$ pada petani di Kelurahan Rurukan yang memiliki kebiasaan merokok menyatakan bahwa sebagian besar mempunyai lesi di daerah palatum. 
Siwi, Pangemanan, Gunawan: Prevalensi stomatitis nikotina pada buruh tambang ...

Tabel 5. Distribusi prevalensi stomatitis nikotina berdasarkan jenis rokok

\begin{tabular}{|c|c|c|c|c|}
\hline \multirow[t]{2}{*}{ Jenis rokok } & & \multicolumn{2}{|c|}{$\begin{array}{l}\text { Lesi yang diduga } \\
\text { stomatitis nikotina }\end{array}$} & \multirow[t]{2}{*}{ Total } \\
\hline & & Ada & Tidak & \\
\hline \multirow{3}{*}{ Putih } & $\mathrm{N}$ & 52 & 12 & 64 \\
\hline & $\%$ dengan jenis rokok & 55,3 & 12,8 & 100 \\
\hline & $\%$ total responden & 81,3 & 18,7 & 100 \\
\hline \multirow{3}{*}{ Kretek } & $\mathrm{N}$ & 1 & 0 & 1 \\
\hline & $\%$ dengan jenis rokok & 1,1 & 0 & 1,1 \\
\hline & $\%$ total responden & 100 & 0 & 100 \\
\hline \multirow{3}{*}{ Campuran } & $\mathrm{N}$ & 21 & 8 & 29 \\
\hline & $\%$ dengan jenis rokok & 22,3 & 8,5 & 30,8 \\
\hline & $\%$ total responden & 72,4 & 27,6 & 100 \\
\hline \multirow{3}{*}{ Total } & $\mathrm{N}$ & 74 & 20 & 94 \\
\hline & $\%$ dengan jenis rokok & 78,7 & 21,3 & 100 \\
\hline & $\%$ total responden & 253,7 & 46,3 & 300 \\
\hline
\end{tabular}

Tabel 6. Prevalensi stomatitis nikotina berdasarkan lama merokok

\begin{tabular}{|c|c|c|c|c|}
\hline \multirow[t]{2}{*}{$\begin{array}{l}\text { Lama merokok } \\
\text { (tahun) }\end{array}$} & & \multicolumn{2}{|c|}{$\begin{array}{l}\text { Lesi yang diduga } \\
\text { stomatitis nikotina }\end{array}$} & \multirow[t]{2}{*}{ Total } \\
\hline & & Ada & Tidak & \\
\hline \multirow{4}{*}{$1-10$} & $\mathrm{~N}$ & 18 & 7 & 25 \\
\hline & $\%$ dengan lama merokok & 19,1 & 7,4 & 93,7 \\
\hline & $\%$ total responden & 72 & 28 & 100 \\
\hline & $\mathrm{N}$ & 20 & 7 & 27 \\
\hline \multirow[t]{2}{*}{$>10-20$} & $\%$ dengan lama merokok & 21,3 & 7,4 & 28,7 \\
\hline & $\%$ total responden & 74,1 & 25,9 & 100 \\
\hline \multirow{3}{*}{$>20$} & $\mathrm{~N}$ & 36 & 6 & 42 \\
\hline & $\%$ dengan lama merokok & 38,3 & 6,5 & 44,7 \\
\hline & $\%$ total responden & 85,7 & 14,3 & 100 \\
\hline \multirow{3}{*}{ Total } & $\mathrm{N}$ & 74 & 20 & 94 \\
\hline & $\%$ dengan lama merokok & 78,7 & 21,3 & 100 \\
\hline & $\%$ total responden & 250,9 & 68,2 & 319,1 \\
\hline
\end{tabular}

Tabel 7. Prevalensi stomatitis nikotina berdasarkan jumlah rokok yang dihisap setiap hari

\begin{tabular}{ccccc}
\hline \multirow{2}{*}{$\begin{array}{c}\text { Jumlah rokok } \\
\text { (batang/hari) }\end{array}$} & & \multicolumn{2}{c}{$\begin{array}{c}\text { Lesi yang diduga } \\
\text { stomatitis nikotina }\end{array}$} & \multirow{2}{*}{ Total } \\
\cline { 3 - 4 } & & Ada & Tidak & \\
\hline \multirow{3}{*}{$<10$} & \% dengan jumlah rokok & 7,4 & 2 & 9 \\
& \% total responden & 77,8 & 2,1 & 9,5 \\
& $\mathrm{~N}$ & 25 & 5 & 100 \\
\multirow{3}{*}{$10-20$} & \% dengan jumlah rokok & 26,6 & 5,3 & 30 \\
& \% total responden & 83,3 & 16,7 & 100 \\
& $\mathrm{~N}$ & 42 & 13 & 55 \\
$>20$ & \% dengan jumlah rokok & 44,7 & 13,8 & 58,5 \\
& \% total responden & 76,4 & 23,6 & 100 \\
\hline \multirow{3}{*}{ Total } & N & 74 & 20 & 94 \\
& \% dengan jumlah rokok & 78,7 & 21,3 & 100 \\
& \% total responden & 237,5 & 62,5 & 300 \\
\hline
\end{tabular}


Pada penelitian ini (Tabel 4) didapatkan sebanyak 74 orang $(78,7 \%)$ dengan stomatitis nikotina. Hal ini disebabkan karena banyaknya jumlah rokok yang dihisap oleh para buruh tambang yang dari suhu asap rokok yang masuk berkontak langsung dengan mukosa palatal, terjadi iritasi sehingga mengakibatkan stomatitis nikotina.

Penelitian ini mendapatkan bahwa sebagian besar subjek penelitian merokok dengan jenis rokok putih yaitu sebanyak 64 orang $(68,1 \%)$, pada 52 orang $(55,3 \%)$ di antaranya terlihat adanya stomatitis nikotina (Tabel 5). Sebagian besar subjek penelitian memilih rokok putih karena harga dari rokok putih lebih terjangkau dibandingkan rokok kretek dan lebih mudah untuk diperoleh. ${ }^{9}$ Dari Tabel 5 juga diketahui bahwa subjek penelitian yang merokok dengan jenis rokok kretek sebanyak 1 orang $(1,1 \%)$, dan jenis rokok campuran sebanyak 29 orang $(30,8 \%)$. Hasil ini sejalan dengan penelitian oleh Mentang ${ }^{10}$ yang mendapatkan $51,8 \%$ perokok menghisap rokok dengan jenis rokok putih. Hasil ini berbeda dibandingkan dengan penelitian yang dilakukan oleh Darongke et al. ${ }^{13}$ yang mendapatkan $67,5 \%$ perokok menghisap rokok dengan jenis rokok kretek dan sebanyak 32,5\% menghisap rokok putih.

Sebagian besar perokok memulai kebiasaan tersebut saat masih usia remaja dan dimulai dengan cara coba-coba. ${ }^{13}$ Dari Tabel 6 diketahui bahwa berdasarkan lama merokok, subjek yang sudah merokok selama 1-10 tahun sebanyak 25 orang (26,6\%), yang sudah merokok selama 11-20 tahun sebanyak 27 orang $(28,7 \%)$, dan yang sudah merokok >20 tahun sebanyak 42 orang $(44,7 \%)$. Berdasarkan lama merokok didapatkan angka tertinggi yaitu pada 36 orang $(38,3 \%)$ terlihat adanya stomatitis nikotina. Hal ini dikarenakan perokok yang merokok >20 tahun sudah lebih lama dan lebih banyak mengonsumsi rokok disbandingkan yang merokok selama 1-10 tahun atau yang merokok selama 11-20 tahun. $^{14}$

Berdasarkan jumlah rokok yang dihisap setiap hari, perokok berat ialah orang yang merokok lebih dari 20 batang per hari. ${ }^{15}$ Pada penelitian ini berdasarkan jumlah rokok yang dihisap setiap hari (Tabel 7) didapatkan bahwa stomatitis nikotina memiliki angka tertinggi yaitu 42 orang $(44,7 \%)$ pada subjek penelitian yang merokok $>20$ batang per hari yaitu 55 orang $(58,5 \%)$. Hal ini dikarenakan aktivitas para buruh tambang yang sudah terbiasa bahkan ketergantungan dengan merokok di waktu senggang, sehingga bisa merokok >20 batang per harinya. Dari Tabel 7 juga diketahui bahwa subjek penelitian yang merokok $<10$ batang per hari sebanyak 9 orang $(9,6 \%)$ dan subjek yang merokok 10 20 batang per hari sebanyak 30 orang $(31,9 \%)$. Hasil ini sejalan dengan penelitian yang dilakukan oleh Mentang ${ }^{10}$ yang menyatakan bahwa subjek penelitian yang merokok $>20$ batang per hari memiliki angka tertinggi yaitu sebesar $37 \% ; 10-20$ batang per hari sebesar 34\%; dan <10 batang per hari sebesar $28,4 \%$. Berbeda dengan penelitian yang dilakukan oleh Darongke et al. ${ }^{13}$ yang menyatakan bahwa perokok yang menjadi subjek penelitian lebih banyak menghabiskan satu bungkus rokok per hari atau 10-20 batang per hari yaitu sebesar 50\%; <10 batang per hari sebesar $46,25 \%$; dan $>20$ batang per hari sebesar $3,75 \%$.

\section{SIMPULAN}

Dari hasil penelitian dan bahasan dapat disimpulkan bahwa sebagian besar buruh tambang yang menderita stomatitis nikotina menghisap rokok dengan jenis rokok putih, sudah merokok selama $>20$ tahun, dan merokok $>20$ batang per hari.

\section{SARAN}

1. Memperhatikan kesehatan gigi dan mulut serta mengurangi konsumsi rokok agar tidak terjadi penyakit dalam rongga mulut yang dapat membahayakan kesehatan.

2. Meningkatkan upaya promosi dan penelitian lebih lanjut mengenai kesehatan gigi dan mulut bagi masyarakat terlebih khusus bagi buruh tambang yang memiliki kebiasaan 
merokok, karena pengetahuan akan kesehatan gigi dan mulut serta dampak dari rokok terhadap rongga mulut masih sangat rendah terutama pada masyarakat dengan status ekonomi menengah ke bawah.

\section{DAFTAR PUSTAKA}

1. Wongkar D, Suba B, Maseda DR. Hubungan pengetahuan dan sikap tentang bahaya merokok dengan perilaku merokok pada remaja putra di SMA Negeri I Tompasobaru. E-journal Keperawatan [serial on the internet]. 2013 Aug [cited 2015 May 9]. Available from: http://ejournal.unsrat.ac.id/index.php/jk p/article/view/2176. h. 1.

2. PSMKGI Masterweb. Bahaya merokok terhadap kesehatan mulut [internet]. 2013 May 31. [cited 2014 Aug 30]. Available from: http://psmkgi.org/bahaya-merokokterhadap-kesehatan-mulut/. h. 1,3.

3. Fauzan H, Hartono B, Susanna D. Penentuan kadar nikotin dalam asap rokok. Makara Kesehatan. 2003;7(2): 38-41.

4. Laskaris G. Atlas Saku Penyakit Mulut (2nd ed). Jakarta: EGC, 2014; p. 1-2, 10-11, 28-9, 86-7.

5. Fawzani N, Triratnawati A. Terapi berhenti merokok (studi kasus 3 perokok berat). Makara Kesehatan. 2005;9(1):15-22.

6. Global Adults Tobacco Survey. Indonesia report [serial on the internet]. 2011 [cited 2014 Sept 4] Available from: http://www.who.int/tobacco/surveillanc e/survey/gats/indonesia_report.pdf. h. 5 .

7. Badan Penelitian dan Pengembangan Kesehatan Departemen Kesehatan Republik Indonesia. Riset Kesehatan Dasar [online]. 2013 [cited 2016 Aug
30]. Available from

http://www.litbang.depkes.go.id/sites/do wnload/rkd2013/Laporan_Riskesdas201 3.pdf. h. 5.

8. Lampus BS, Djokja RM, Mintjelungan C. Gambaran perokok dan angka kejadian lesi mukosa mulut di Desa Monsongan Kecamatan Banggai Tengah. e-GiGi. 2013;1(1):38-44.

9. Mulalinda SL, Suling PL, Mintjelungan CN. Lesi yang diduga stomatitis nikotina pada nelayan yang memiliki kebiasaan merokok. 2015. [cited 2016 Aug 6]. Available from: http://ejournal.unsrat.ac.id/index.php/ph armacon/article/download/10197/9784. h. 90-1.

10. Mentang RYJ. Gambaran lesi yang diduga stomatitis nikotina pada buruh yang memiliki kebiasaan merokok di pelabuhan Manado. [Skripsi]. Manado: Universitas Sam Ratulangi; 2012.

11. Axel T, Hedin CA. Oral melanin pigmentation in 467 Thai and Malaysian people with special emphasis on smoker's melanosis. Journal of Oral Pathology and Medicine 2006. [serial on the internet]. Available from: http://onlinelibrary.wiley.com/doi/10.11 11/j.16000714.1991.tb00879.x/epdf?r3_referer= wol\&tracking_action=preview_click\&s how_checkout $=1 \&$ purchase_referrer $=0$ nlinelibrary.wiley.com\&purchase_site_1 icense=LICENSE_DENIED.

12. Kang ZK. Hubungan kebiasaan merokok dengan terjadinya stomatitis nikotina pada pegawai non-akademik Universitas Sumatera Utara [Skripsi]. Medan: Universitas Sumatera Utara; 2012.

13. Darongke G, Wowor VNS, Lampus B. Status gingiva dan kejadian lesi putih pada perokok. Dentire 1. 2013;2(1):30-3. 